\title{
Sensory and Physical Properties of Pla-duk-ra (Dried Fermented Catfish) at Different Conditions of Drying
}

\author{
Siti Azhani ${ }^{1}$, Adilan Hniman ${ }^{2}$, Nattaya Laehmad ${ }^{2}$, Sherly Hanifarianty ${ }^{3}$, Payap Masniyom ${ }^{2,4 *}$, \\ Tawat Noipom ${ }^{2}$, Makatar Wae-hayee ${ }^{2}$ \\ ${ }^{1}$ Agrotechnology, Faculty of Agro Based Industry, Universiti Malaysia Kelantan, Locked Bag No. 100, 17600 Jeli, Malaysia \\ Email: ctsuju95@gmail.com
}

${ }^{2}$ Halal Institutes, Prince of Songkla University, Hatyai, Songkhla 90112, Thailand.

Email: tawat.n@psu.ac.th, makatar.w@psu.ac.th

\author{
${ }^{3}$ Sembawa Research Center, Indonesian Rubber Research Institute (IRRI), Jln. Raya Palembang-Betung KM. 29, P.O. BOX 1127, Palembang, \\ South Sumatera, 30001, Indonesia \\ Email: sherlyhanifarianty@gmail.com \\ ${ }^{4}$ Department of Technology and Industries, Faculty of Science and Technology, Prince of Songkla University, Pattani, Thailand. \\ Corresponding author e-mail: payap.mepsu.ac.th
}

\begin{abstract}
In southernmost Thailand, big scale production of catfish demands a development of new lines of catfish-based products to fully utilize the raw material. Pla-duk-ra (dried fermented catfish) is one such innovation. Traditional method of sunlight drying is commonly used to dry Pla-duk-ra. However, products are highly prone to contamination since they are dried in exposed area. Direct exposure to sunlight could also affect heat labile and light-sensitive nutrients. In this study, other methods of drying were investigated to dry Pla-duk-ra with improved hygiene practice, physical properties and sensory profile. Two scenarios were studied in this work. The objective of the first scenario was to determine the best range of temperature to dry a good and acceptable Pla-duk-ra by comparing open sun drying (range $40^{\circ} \mathrm{C}$ to $50^{\circ} \mathrm{C}$ ) and shade drying (under the roof; $30^{\circ} \mathrm{C}$ to $40^{\circ} \mathrm{C}$ ) . The best range of temperature obtained was then used for the second scenario where open sun, infrared and tray drying were further studied. Moisture content, water activity, colour, texture profile analysis were performed on the Pla-duk-ra samples. Fried Pla-duk-ra was used in sensory evaluation to investigate consumer's acceptance and preference. Open sun drying was found to be more superior to dry Pla-duk-ra resulting in darker shade of product as compared to shade drying. The moisture content for open sun drying and shade drying of Pladuk-ra were reported $23.65 \%$ and $28.06 \%$, respectively. Infrared heater gave the highest water activity $(0.77)$ with the highest score for redness. Meanwhile, Pla-duk-ra dried under the hot-air tray resulted in the highest score for brightness $\left(L^{*}\right)$. Overall acceptance by the consumer showed that the Pla-duk-ra dried under the hot-air tray was the most preferred followed by open sun drying and infrared heater drying. To this end, hot-air tray drying could be applied in drying Pla-duk-ra in large scale production.
\end{abstract}

Keywords - Pla-duk-ra; fermented catfish; open sun drying; shade drying; infrared; hot-air tray; sensory profile; physical properties.

\section{INTRODUCTION}

Pla-duk-ra is a dried fermented catfish which can be found in southern Thailand. In this region of the country, catfish is consumed by a large population. Many catfish industries are located here following Government's initiatives to provide land and facilities to help develop entrepreneurial skills in the community and improve their economic status. One such location of catfish industry is at
Hutan Tua Khokkhian, Ban Bajoh Industry Narathiwat, Thailand. Despite the steady production, (fresh) catfish is only served and cooked in meals. Other types of catfishbased products are non-existence except for Pla-duk-ra. In line with the Government's effort in catfish industry, there is a huge potential to produce catfish in a big capacity hence the need to develop new lines of catfish-based products to fully utilize the raw material. In addition, fresh catfish has short shelf life as compared to dried/fermented products. The latter is a convenient alternative as they can be easily 
packed, transported and incorporated into various food preparations.

Catfish is a high source of protein. Most people do not eat catfish due to the fishy smell and the mucus present. Interestingly, Pla-duk-ra has reduced fishy smell with good aroma due to its fermentation with brown sugar. Following fermentation, Pla-duk-ra is dried to extend shelf-life and delay spoilage as drying can reduce moisture content and improve water activity $\left(\mathrm{a}_{\mathrm{w}}\right)$, hence minimizing microbial metabolic activity.

Based on previous study, direct sunlight is the most common traditional and cheap method of food drying in tropical and subtropical regions [1]. However, most of the heat labile and light-sensitive nutrients may be lost due to direct exposure to sunlight and oxygen [2]. The same authors reported that drying of fruits under direct sunlight and polyethylene covered solar drying method caused $84 \%$ and $71 \%$ ascorbic acid losses, respectively [2]. Another study proves that the sun drying method does not only have negative effects on the preservation of ascorbic acid content but also damages the colour quality of end products [3].

Pla-duk-ra is commonly dried using traditional way under the sunlight. However, sunlight drying exposes the material to potential contamination from the environment. As such, this present study was set to investigate the potential use of other drying methods in addition to sunlight drying (open sun and shade drying), infrared and hot air drying; and their effects on sensory and physical properties of Pla-duk-ra.

\section{MATERIAL AND METHOD}

Two scenarios were studied in this work. The objective of the first scenario was to determine the best range of temperature to dry a good and acceptable Pla-duk-ra by comparing open sun drying and shade drying (under the roof). In this case, open sun drying was considered as high temperature (range $40^{\circ} \mathrm{C}$ to $50^{\circ} \mathrm{C}$ ) and shade drying was considered as low temperature $\left(30^{\circ} \mathrm{C}\right.$ to $\left.40^{\circ} \mathrm{C}\right)$. The best range of temperature obtained was then used for the second scenario.

The objective of the second scenario was to investigate the different methods of drying the Pla-duk-ra namely open sun, infrared and tray drying. The result of analysis from Pla-duk-ra dried under the open sun was used as a benchmark to compare with infrared and tray drying.

\section{A. Preparation of Fermented Catfish}

In this study, $2 \mathrm{~kg}$ of small size (about $6 \mathrm{~cm}-8 \mathrm{~cm}$ ) raw matured catfish was fermented with brown sugar and salt with a ratio of $3: 2$. Fig. 1 shows the process of producing Pla-duk-ra which results in final physical changes of skin colour. It took in total two days to produce a Pla-duk-ra. First, raw catfish was cleaned by removing the head, inner organ and blood (Fig. 1(a)). Then, the brown sugar-salt mixture was spread onto the catfish including inside the incision of the body of catfish to make sure uniform fermentation (Fig. 1(b)). The fermentation was carried out overnight prior to drying in open sun and under the shade, respectively. After that, the samples were fermented again (using the same ratio of brown sugar and salt) for overnight at the same temperature. The change of skin colour of fermented catfish after 12 hours of fermentation can be seen during second day of fermentation as shown in Fig. 1(c). Following second fermentation, samples were dried under open sun and shade, respectively. Fig. 1(d) and (e) show the final physical changes of Pla-duk-ra during second day of drying.
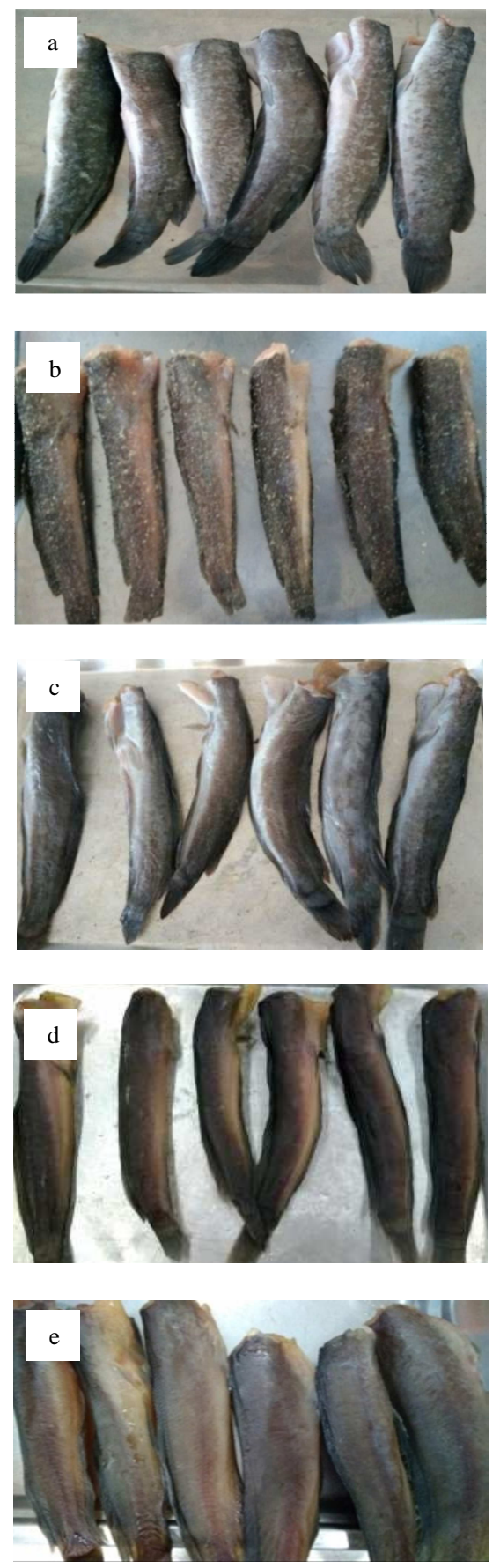

Fig. 1 An Observation of the hanges in skin colour of Pla-duk-ra due to different drying methods used. (a) raw catfish, (b) first fermentation of catfish with sugar and salt, (c) fermented catfish after 12 hours during night time (second day), (d) reddish hue of Pla-duk-ra after two days of open sun drying, and (e) yellowish hue of Pla-duk-ra after two days of shade drying 


\section{B. Condition of Drying}

In this study, open sun drying (Fig. 2), shade drying (Fig. 3), infrared heater drying (Fig. 4) and hot-air tray drying (Fig. 5) were investigated towards the production of Pladuk-ra. First, six marinated catfishes were placed on the tray for each drying method. The samples were arranged in $4 \mathrm{~cm}$ distance to make sure that air can be removed uniformly to every part of the fermented catfish. Additionally, the samples were flipped at hourly interval to ensure the efficiency of evaporation process. The drying temperature was measured by using Infrared (IR) camera at range of $40^{\circ} \mathrm{C}$ to $50^{\circ} \mathrm{C}$. Weight of samples was also recorded at hourly interval to determine the rate of water loss. The same steps were repeated for the second day of drying.

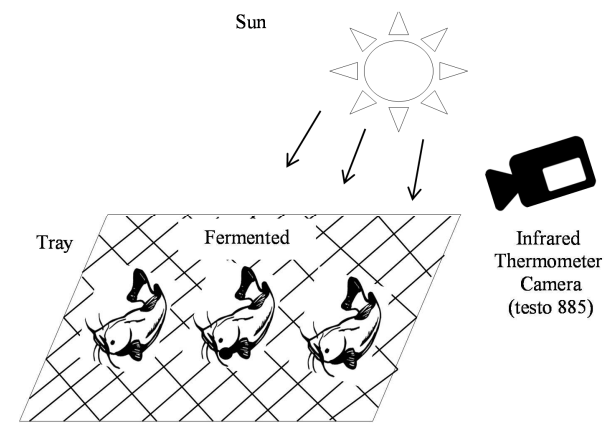

Fig. 2 Open sun drying of Pla-duk-ra

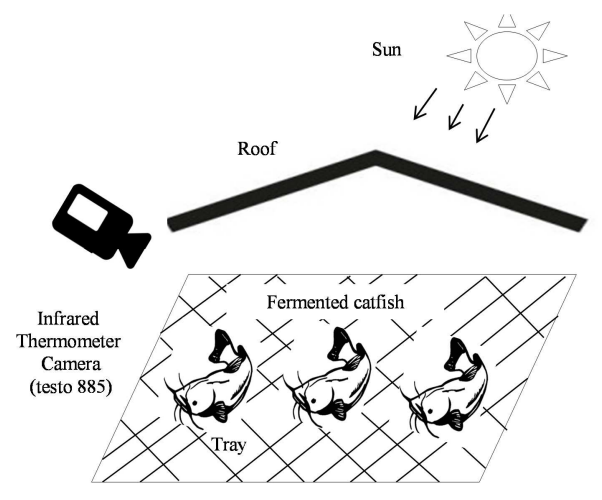

Fig. 3 Shade drying of Pla-duk-ra

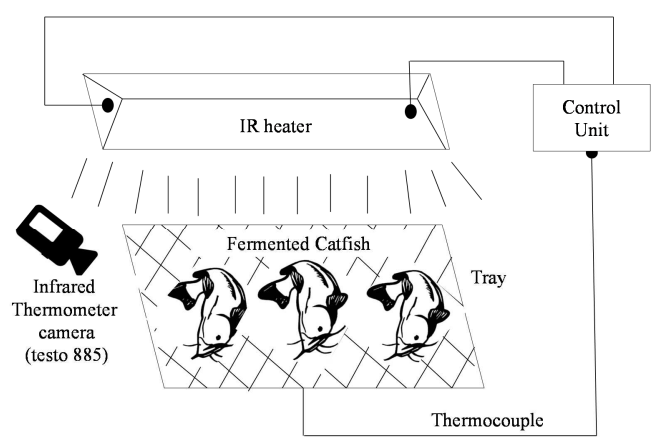

Fig. 4 Infrared heater drying of Pla-duk-ra

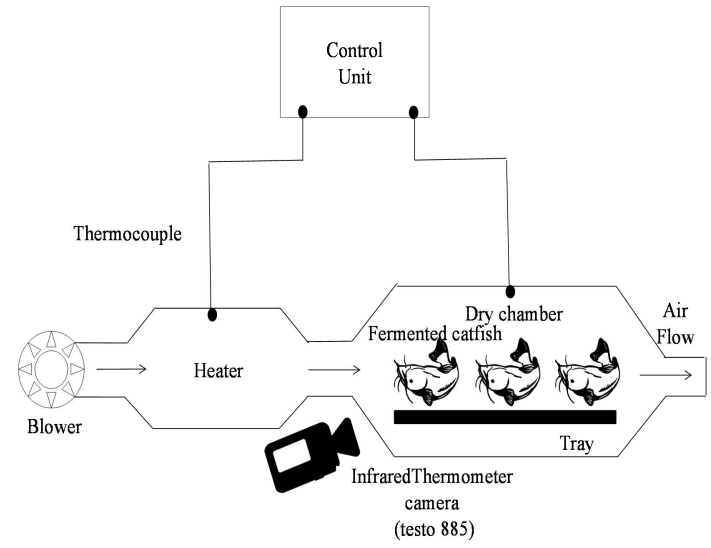

Fig. 5 Hot-air tray drying of Pla-duk-ra

\section{Evaluation of Quality of Pla-duk-ra}

1) Determination of Temperature: The temperature of Pla-duk-ra during drying process was measured by using Infrared (IR) thermometer camera (Testo 885) and interpreted using IR software. Infrared thermometer camera captured and measured the temperature based on thermal radiation surrounding the samples of Pla-duk-ra. This method is more accurate compared to digital thermometer since it can measure the average temperature for each sample of Pla-duk-ra and provide profile line of temperature. The temperature was monitored and recorded every hour in order to maintain the accurate target range of temperature during drying. The position and angle of Infrared camera was adjusted to $130^{\circ}$ as it can capture for whole part of samples. The position of Infrared thermometer camera is as shown in Fig. 2 until Fig. 5.

2) Weight Loss of Pla-duk-ra: The rate of water loss was determined by measuring the weight loss for each sample of Pla-duk-ra. The weight of Pla-duk-ra was taken for the first thirty minutes and at every hour after that using electronic weighing balance.

3) Water Activity: Measurement of water activity was carried out using AQUALAB Benchtop Water Activity Meter in order to estimate shelf life and potential microbial growth. Three replicates of $1 \mathrm{~g}$ sample from each condition of open sun and shade drying; were taken. Calibration value around 0.988 was obtained prior to sample measurement by using distilled water [5].

4) Moisture Content: Moisture analysis was carried out to determine the rate of water loss in samples samples in comparison to the loss of mass. Microbial content in (food) sample is also commonly related to water content. Sartorius MA35-5VI Moisture Analyser was used for this experiment. Three samples for each condition were measured. Percentage of moisture content was recorded.

5) Colour Measurement: Colorimeter (Konica Minolta Colorimeter model CM-3500d, USA), obtained from food laboratory, Universiti Malaysia Kelantan (UMK), Jeli campus; was used to determine the color for all the samples of Pla-duk-ra with two different methods of drying. Three attributes were analyzed which were $\mathrm{L}^{*}, \mathrm{a}^{*}$ and $\mathrm{b}^{*}$, respectively. $\mathrm{L}^{*}$ represents brightness where whiteness increases with readings (0 to 100) and correlated with structure changes in the fish meat [3]. Meanwhile, a* 
represents green for negative values and red for positive value, and parameter $b^{*}$ indicates blue for negative value and yellow for positive value. A reading of $a^{*}, L^{*}$ and $b^{*}$ were taken in six replicates and the means of the reading were recorded. This analysis was carried on Pla-duk-ra dried under open sun, infrared heater and hot-air tray drying.

6) Texture Profile Analysis: The profile Analysis (TPA) of Pla-duk-ra from each drying method was carried out using Brookfield CT3 Texture Analysis with 5000/g load cell. The analysis was conducted in the laboratory of Universiti Malaysia Kelantan (UMK) Jeli campus. Each sample of Pla-duk-ra (approximately $3 \mathrm{~cm}$ in diameter and $30 \mathrm{~mm}$ in thickness) was placed perpendicular to the blade on the heavy duty platform of the instrument. The blade was calibrated to start at $10 / \mathrm{mm}$ above the testing platform. Once commenced, the blade moves down at $2 \mathrm{~mm} / \mathrm{sec}$ to a distance of $0.1 \mathrm{~mm}$ above the platform during which time the Pla-dukra samples were cut and the firmness measured from the peak force.

7) Consumer's Survey (Sensory Profile): The most important sensory attributes of Pla-duk-ra were texture, colour and flavour. The sensory evaluation was carried out on the Pla-duk-ra dried using the three different methods, respectively. The samples of Pla-duk-ra were fried before being served to panel of evaluators. The survey was carried out in the Food Laboratory of University Malaysia Kelantan. Thirty (30) evaluators consisting of UMK's students, staff and lecturers were selected randomly to evaluate the acceptability of Pla-duk-ra produced using different drying methods. the form provided. Hardness (texture), colour, aroma, flavour and overall acceptance were tested by using 7 scales based on Hedonic sensory's survey form.

8) Statistical Analysis: All experiments were run in six replicates. Data were subjected to analysis of variance (ANOVA) using SPSS (2010). Significant means were compared at 5\% probability level using Duncan's Multiple Range Test (DMRT).

\section{RESULTS AND DISCUSSION}

\section{A. The temperature of Drying Pla-duk-ra}

The temperature distributions and profile measured using Infrared Thermometer Camera (Testo 885) of drying Pladuk-ra at different conditions are shown in Fig. 6(a) and 7(a) for open sun drying, Fig. 8(a) and 9(a) for shade drying, Fig. 10(a) and 11(a) for infrared heater drying and Fig. 12(a) and 13(a) for hot-air tray drying. Also, the average temperature of drying Pla-duk-ra at different conditions is shown in Table I for open sun drying, Table II for shade drying, Table III for infrared heater drying and Table IV for hot-air tray drying.

The temperature of drying Pla-duk-ra for the case of open sun drying was higher than the case of shade drying. Due to this, range of both infrared heater drying and hot-air tray drying was controlled to be the same as the temperature range observed in open sun drying. The average temperature was approximately $44{ }^{\circ} \mathrm{C}$.

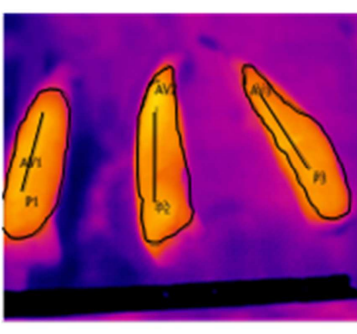

(a) Temperature

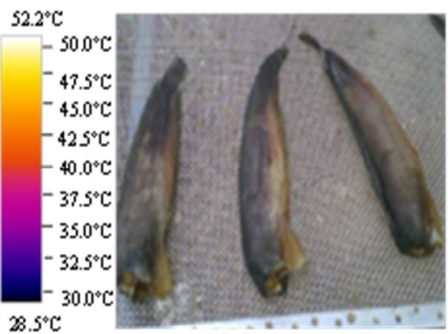

(b) Photo
Fig. 6 Temperature reading and distribution of heat in Pla-duk-ra dried under open sun

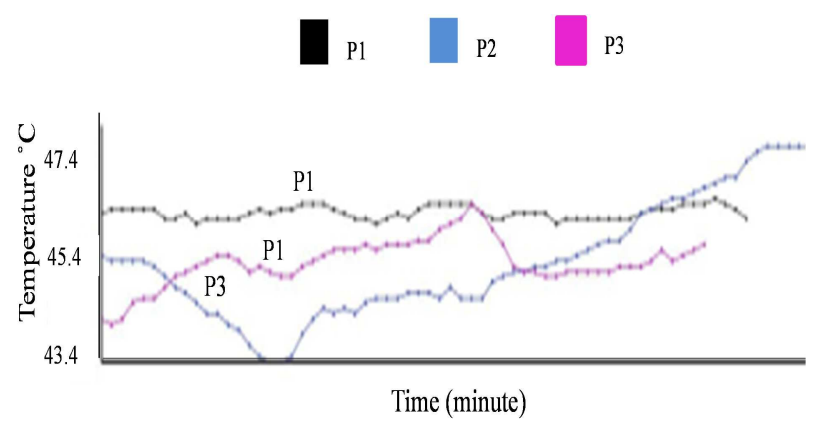

Fig. 7 Profile line of temperature for open sun drying

TABLE I

Average Temperature OF Drying Pla-DuK-RA For OPEN SUN DRYING

\begin{tabular}{|c|c|}
\hline Measurement objects & Temperature $\left({ }^{\circ} \mathbf{C}\right)$ \\
\hline Average area of sample 1 & 43.8 \\
\hline Average area of sample 2 & 44.4 \\
\hline Average area of sample 3 & 43.8 \\
\hline Total average area of samples & 44.0 \\
\hline
\end{tabular}

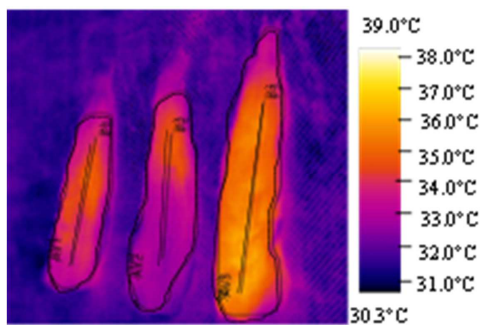

(a) Temperature

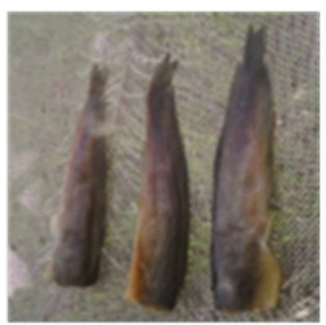

(b) Photo
Fig. 8 Temperature reading and distribution of heat in Pla-duk-ra dried under shade drying

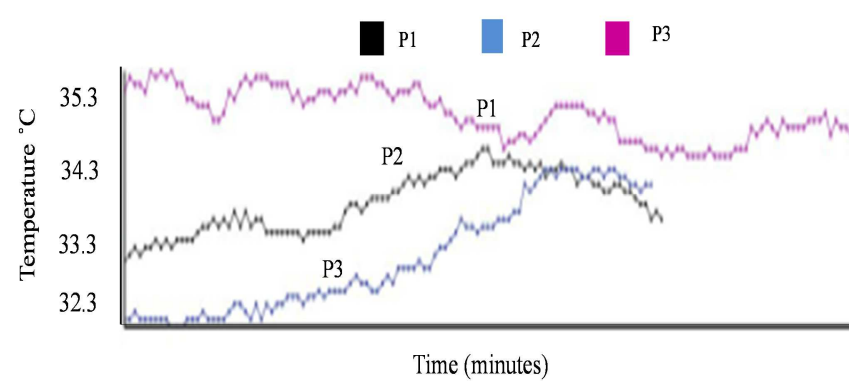

Fig. 9 Profile line of temperature for Pla-duk-ra dried under shade 
TABLE II

Average Temperature Of DRYing Pla-DuK-RA For SHADE Drying

\begin{tabular}{|c|c|}
\hline Measurement objects & Temperature $\left({ }^{\circ} \mathbf{C}\right)$ \\
\hline Average area of sample 1 & 33.6 \\
\hline Average area of sample 2 & 33.0 \\
\hline Average area of sample 3 & 34.6 \\
\hline Total average area of samples & 33.7 \\
\hline
\end{tabular}

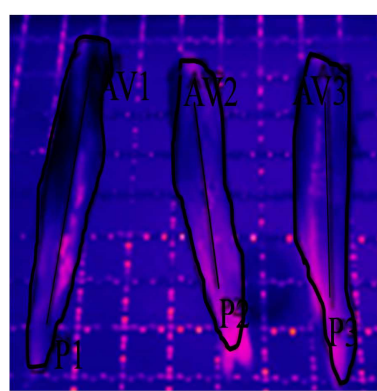

(a) Temperature

Fig. 10 Temperature reading and distribution of heat in Pla-duk-ra dried using infrared heater drying

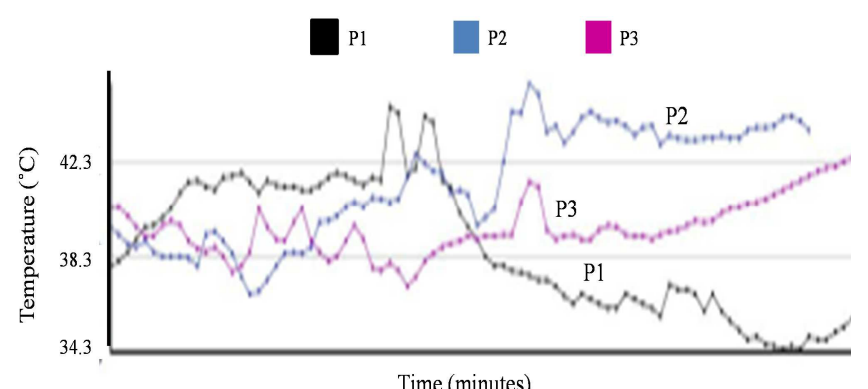

Fig. 11 Profile line of temperature of Pla-duk-ra dried using infrared heater drying

TABLE III

AVERAGe TEMPERATURE OF DRYING PLA-DUK-RA FOR INFRARED HEATER DRYING

\begin{tabular}{|c|c|}
\hline Measurement objects & Temperature $\left({ }^{\circ} \mathbf{C}\right)$ \\
\hline Average area of sample 1 & 39.7 \\
\hline Average area of sample 2 & 41.0 \\
\hline Average area of sample 3 & 40.0 \\
\hline Total average area of samples & 44.2 \\
\hline
\end{tabular}

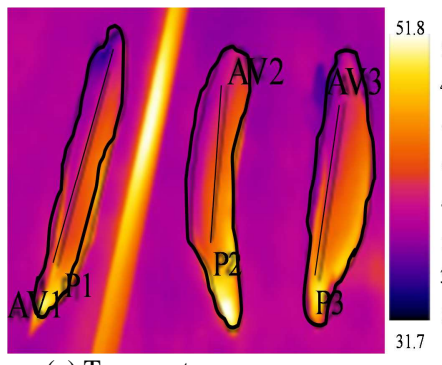

(a) Temperature

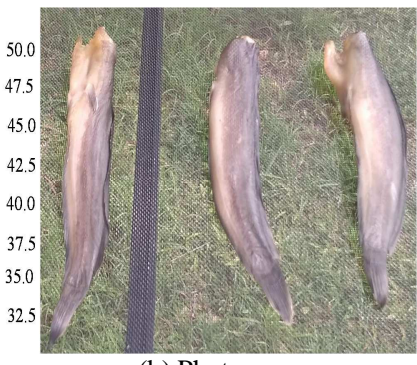

heat in Pla-duk-ra dried using hot-air tray drying

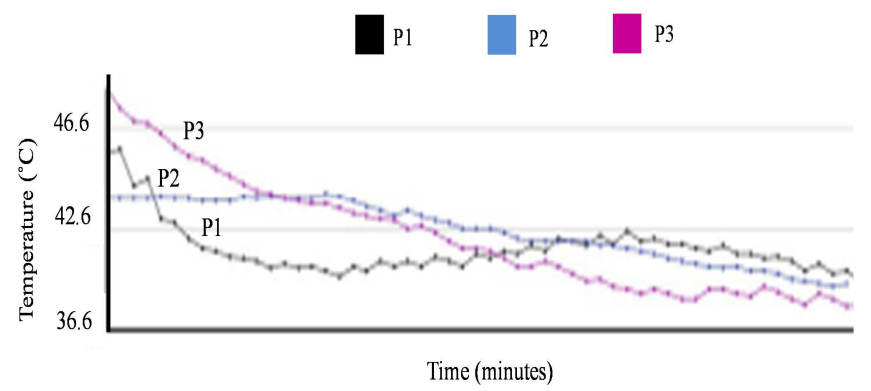

Fig. 13 Profile line of temperature of Pla-duk-ra dried using tray drying

TABLE IV

Average Temperature of Drying Pla-DuK-RA For Hot-AIR TRAY DRYING

\begin{tabular}{|c|c|}
\hline Measurement objects & Temperature $\left({ }^{\circ} \mathbf{C}\right)$ \\
\hline Average area of sample 1 & 41.6 \\
\hline Average area of sample 2 & 42.8 \\
\hline Average area of sample 3 & 43.3 \\
\hline Total average area of samples & 44.2 \\
\hline
\end{tabular}

B. Weight of Pla-duk-ra with Time Taken to Dry

Fig. 14 shows the weight of Pla-duk-ra obtained using shade drying and open sun drying. At starting point, the weight of Pla-duk-ra are the same as $150 \mathrm{~g}$ for both shade drying and open sun drying. After 30 minutes, the weight of Pla-duk-ra decreased immediately to $140 \mathrm{~g}$ and $130 \mathrm{~g}$ for shade drying and open sun drying, respectively. After that, the weight of Pla-duk-ra for both shade drying and open sun drying became constant. On the other hand, the weight of Pla-duk-ra decreased eventually from $140 \mathrm{~g}$ to $130 \mathrm{~g}$ for shade drying, and then it is remain constant. It can be noted that the weight of Pla-duk-ra for shade drying showed more weight until 120 minutes of time taken compared to the weight of Pla-duk-ra for open sun drying.

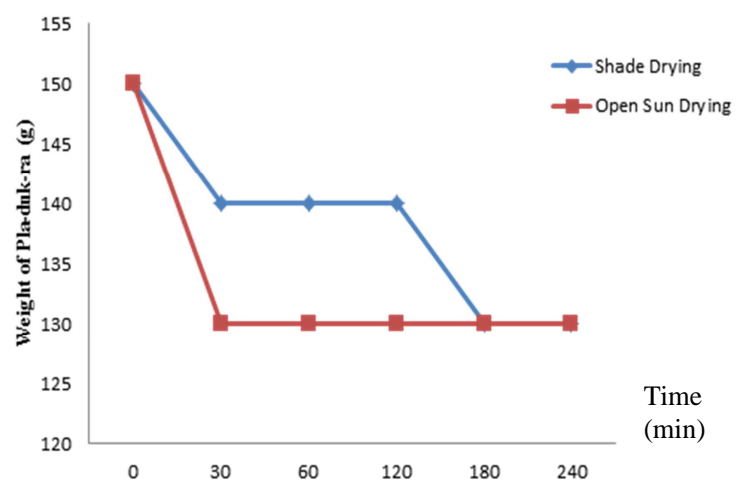

Fig. 14 Weight of sample (Pla-duk-ra) with the time taken to dry based on open sun and shade drying

\section{Water Activity, $a_{w}$ and Moisture Content of Pla-duk-ra} Dried under Open Sun and Shade Drying

Based on Table V, the moisture content of Pla-duk-ra from open sun drying was $23.65 \%$; which was significantly higher than shade drying $(28.06 \%)$ where $p<0.05$. The higher the moisture content, the lower the percentage for fish to be perishable [2]. The moisture content of a food product is referred to the amount of water loss from the food. A low percentage of moisture content is a good for a food product since it can prevent microbial growth. 
The water activity $\left(\mathrm{a}_{\mathrm{w}}\right)$ of Pla-duk-ra dried under the open sun and shade drying was found to be at 0.75 and 0.77 , respectively. High water activity could be related to microbial growth [6]. In the case of Pla-duk-ra dried using sunlight drying, the potential microbial growth could be from mold species such as Aspergillus which is common in the environment. In a previous study, higher value of water activity was recorded [4] as compared to this present study. This is probably due to the differences in size of catfish used. Species of Clarias gariepinus is often bigger than Clarias microcephalus. Based on this present study, a high temperature at a range of $40^{\circ} \mathrm{C}$ to $50^{\circ}$ is suitable to dry a good Pla-duk-ra; and this could be obtained through drying process under the open sun.

TABLE V

Moiture Content AND WATER ACTIVITy OF SAMPle (Pla-DuK-RA) OBTAINED FROM OPEN SUN AND SHADE DRYING

\begin{tabular}{|l|l|c|}
\hline Drying method & \multicolumn{2}{|c|}{ Mean \pm Standard deviation } \\
\cline { 2 - 3 } & $\begin{array}{l}\text { Moisture content, } \\
(\%)\end{array}$ & $\begin{array}{l}\text { Water activity, } \\
\mathbf{a}_{\mathbf{w}}\end{array}$ \\
\hline Open sun drying & $23.65 \pm 3.23^{\mathrm{b}}$ & $0.75 \pm 0.02^{\mathrm{a}}$ \\
\hline Shade drying & $28.06 \pm 1.87^{\mathrm{ab}}$ & $0.77 \pm 0.03^{\mathrm{a}}$ \\
\hline
\end{tabular}

D. Physical changes of Pla-duk-ra based on open sun and shade drying

Fig. 15(a) shows Pla-duk-ra that was dried under the open sun. The skin colour was darker compared to the yellowish skin colour of Pla-duk-ra that was dried under the shade (Fig. 15(b)). Thanonkaew, et al (2009) [3] investigated the chemical compositions and some properties of Pla-duk-ra reared in Phatthalung province in Thailand. It was reported that the skin colour of Pla-duk-ra turns dark after drying under the open sun [3]. To this end, it could be concluded that the heat emission to the Pla-duk-ra affect the skin colour changes; as heat has been associated change in properties of food materials and products [7]-[12].
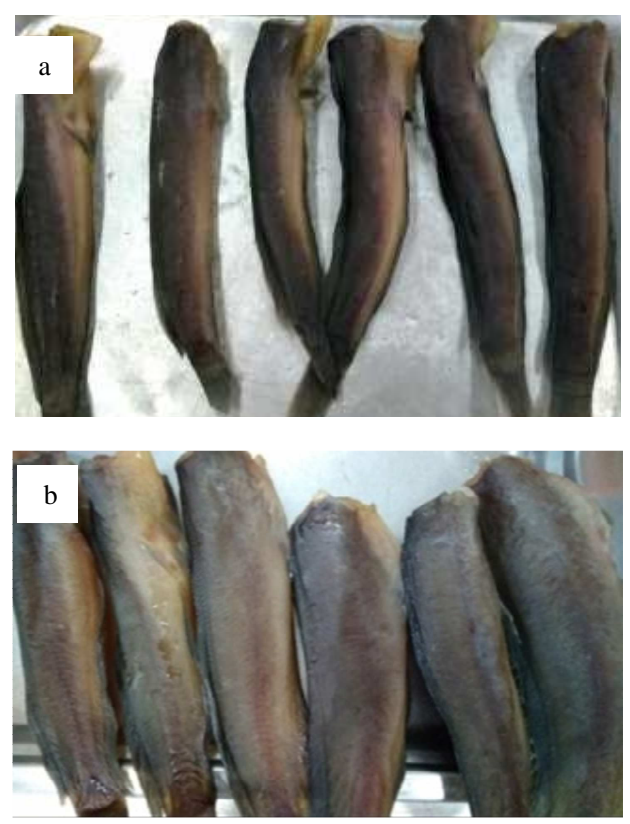

Fig. 15 The change of skin colour of Pla-duk-ra dried under different conditions; (a) open sun drying, and (b) shade drying
E. Water Activity, $a_{w}$ and Colour Analysis of Pla-duk-ra Obtained from Open Sun, Infrared Heater and Hot-air Tray Dryings.

Table VI below shows the water activity and colour analysis of Pla-duk-ra obtained from open sun, infrared heater and hot-air tray dryings. The highest water activity $a_{w}$ shown was Pla-duk-ra dried under the infrared heater drying and followed by open sun and hot-air tray drying. Meanwhile, results of the colour test showed that Pla-duk-ra dried under the infrared heater scored high value of $a^{*}$ (redness) and $b^{*}$ (yellowness). Typically, the formation of metmyoglobin in the meat would change the meat colour to brownish red [3]. $\mathrm{L}^{*}$ parameter from colorimeter showed brightness in the following manner; hot-air tray drying > infrared heater $>$ open sun drying.

TABLE VI

The Water Activity AND Colour ANALYsis Of PLA-DuK-RA ObTaINED From OpEn Sun, INFRAREd HEATER AND Hot-Air TRAY DRYINGS

\begin{tabular}{|l|c|c|c|c|}
\hline \multirow{2}{*}{$\begin{array}{l}\text { Drying } \\
\text { method }\end{array}$} & \multicolumn{4}{|c|}{ Mean \pm Standard Deviation } \\
\cline { 2 - 5 } & $\begin{array}{l}\text { Water } \\
\text { activity, } \mathbf{a}_{\mathbf{w}}\end{array}$ & $\mathbf{L}^{*}$ & $\mathbf{a}^{*}$ & $\mathbf{b}^{*}$ \\
\hline $\begin{array}{l}\text { Open } \\
\text { sun } \\
\text { drying }\end{array}$ & $0.75 \pm 0.02^{\mathrm{a}}$ & $23.65 \pm 3.23^{\mathrm{b}}$ & $2.12 \pm 0.51^{\mathrm{b}}$ & $7.78 \pm 0.80^{\mathrm{b}}$ \\
\hline $\begin{array}{l}\text { Infrared } \\
\text { drying }\end{array}$ & $0.77 \pm 0.03^{\mathrm{a}}$ & $28.06 \pm 1.87^{\mathrm{ab}}$ & $3.65 \pm 0.71^{\mathrm{a}}$ & $10.25 \pm 0.82^{\mathrm{a}}$ \\
\hline $\begin{array}{l}\text { Tray } \\
\text { drying }\end{array}$ & $0.70 \pm 0.02^{\mathrm{b}}$ & $31.23 \pm 1.57^{\mathrm{a}}$ & $1.74 \pm 0.28^{\mathrm{b}}$ & $6.44 \pm 0.71^{\mathrm{b}}$ \\
\hline
\end{tabular}

L* (brightness), a* (redness), b* (yellowness)

\section{F. $\quad$ Texture Profile Analysis (TPA) of Pla-duk-ra Obtained from Open Sun, Infrared Heater and Hot-air Tray Dryings}

Table VII shows the texture profile analysis of Pla-duk-ra obtained from open sun, infrared heater and hot-air tray drying. Pla-duk-ra dried under open sun drying showed the highest value of hardness, adhesiveness, cohesiveness and gumminess as compared to other types of drying $(p<0.05)$. Meanwhile, the highest score of chewiness was Pla-duk-ra dried under the infrared heater (611.57) and followed by open sun (680.33) and tray drying (432.63) where $p<0.05$. Sample from infrared drying indicated the lowest scores for hardness, adhessiveness, cohesiveness and gumminess. Overall, it can be pointed out that high emission of heat caused physical changes to samples .

TABLE VII

TEXTURe Profile OF Pla-DuK-RA OBTAINED From OPEN SUN, INFRARED HEATER AND HOT-AIR TRAY DRYING

\begin{tabular}{|l|c|c|c|c|c|}
\hline \multirow{2}{*}{$\begin{array}{l}\text { Drying } \\
\text { method }\end{array}$} & \multicolumn{5}{|c|}{ Mean \pm Standard Deviation } \\
\cline { 2 - 6 } & Hardness & Adhesiveness & Cohesiveness & Gumminess & Chewiness \\
\hline $\begin{array}{l}\text { Open } \\
\text { sun } \\
\text { drying }\end{array}$ & $5158.67 \pm 66.58^{\mathrm{a}}$ & $1.47 \pm 0.40^{\mathrm{b}}$ & $1.46 \pm 0.22^{\mathrm{b}}$ & $7602.66 \pm 1171.55^{\mathrm{a}}$ & $611.57 \pm 89.76^{\mathrm{a}}$ \\
\hline $\begin{array}{l}\text { Infrared } \\
\text { drying }\end{array}$ & $5130.67 \pm 88.01^{\mathrm{a}}$ & $0.37 \pm 0.31^{\mathrm{b}}$ & $0.92 \pm 0.41^{\mathrm{a}}$ & $4707.33 \pm 2056.72^{\mathrm{a}}$ & $680.33 \pm 295.97^{\mathrm{a}}$ \\
\hline $\begin{array}{l}\text { Tray } \\
\text { drying }\end{array}$ & $5134.00 \pm 106.59^{\mathrm{a}}$ & $1.40 \pm 0.36^{\mathrm{a}}$ & $1.00 \pm 0.13^{\mathrm{b}}$ & $5165.33 \pm 697.17^{\mathrm{a}}$ & $432.63 \pm 80.78^{\mathrm{a}}$ \\
\hline
\end{tabular}




\section{G. Consumer's Preference of Pla-duk-ra Dried Under Different Conditions}

Table VIII represents sensory evaluation with five attributes of Pla-duk-ra dried under open sun, infrared heater and hot-air tray dryings. It is important to note that the samples were fried before being served, as such the results were directly referring to consumer acceptance towards fried Pla-duk-ra. Io particular, Pla-duk-ra dried under the hot-air tray drying gave the highest scores for all the attributes compared to open sun and infrared drying. Colour score was observed to be in the manner of tray (5.57)> infrared heater (5.37) $>$ and open sun (4.97). Meanwhile, infrared drying scored the least for aroma. Thus, the overall acceptance by the consumer showed that the Pla-duk-ra dried under the hot-air tray was most preferred followed by open sun drying and infrared heater drying. A good Pla-duk-ra that can be accepted the most by the consumers was the Pla-duk-ra with good colour, aroma, flavour and texture.

TABLE VIII

The Sensory Evaluation With Five AtTRibutes Of Pla-Duk-RA OBTAINED FROM OPEN SUN, INFRARED HEATER AND HOT-AIR TRAY DRYINGS.

\begin{tabular}{|l|c|c|c|c|c|}
\hline \multirow{2}{*}{$\begin{array}{l}\text { Drying } \\
\text { method }\end{array}$} & \multicolumn{5}{|c|}{ Mean \pm Standard Deviation } \\
\cline { 2 - 6 } & Colour & Aroma & Flavour & $\begin{array}{c}\text { Texture } \\
\text { (hardness) }\end{array}$ & $\begin{array}{c}\text { Overall } \\
\text { acceptance }\end{array}$ \\
\hline $\begin{array}{l}\text { Open } \\
\text { sun } \\
\text { drying }\end{array}$ & $4.97 \pm 1.61^{\mathrm{a}}$ & $5.20 \pm 1.75^{\mathrm{a}}$ & $5.50 \pm 1.60^{\mathrm{a}}$ & $5.53 \pm 1.07^{\mathrm{a}}$ & $5.83 \pm 1.32^{\mathrm{a}}$ \\
\hline $\begin{array}{l}\text { Infrared } \\
\text { drying }\end{array}$ & $5.37 \pm 1.61^{\mathrm{a}}$ & $5.03 \pm 1.63^{\mathrm{a}}$ & $5.53 \pm 1.55^{\mathrm{a}}$ & $5.77 \pm 1.07^{\mathrm{a}}$ & $5.80 \pm 1.35^{\mathrm{a}}$ \\
\hline $\begin{array}{l}\text { Tray } \\
\text { drying }\end{array}$ & $5.57 \pm 1.34^{\mathrm{a}}$ & $5.23 \pm 1.41^{\mathrm{a}}$ & $5.73 \pm 1.31^{\mathrm{a}}$ & $5.83 \pm 1.12^{\mathrm{a}}$ & $6.00 \pm 1.26^{\mathrm{a}}$ \\
\hline
\end{tabular}

\section{CONCLUSIONS}

Open sun drying (range between $40-50^{\circ} \mathrm{C}$ ) was found to be more superior to dry Pla-duk-ra resulting in darker shade of product as compared to shade drying. The moisture content for open sun drying and shade drying of Pla-duk-ra were reported $23.65 \%$ and $28.06 \%$, respectively. Using the optimal range of temperature obtained, effects of three drying methods (open sun, infrared heater and hot-air tray) on physical and sensory profile of Pla-duk-ra were further investigated. Infrared heater gave the highest water activity with highest score for redness. Overall acceptance by the consumer showed that the Pla-duk-ra dried under the hot-air tray was most preferred followed by open sun drying and infrared heater drying.

\section{NOMENCLATURE}

water activity

moisture content

$\mathrm{a}_{\mathrm{w}}$

$\%$

$\mathrm{T}$ temperature

IR infrared

TPA texture profile analysis

\section{ACKNOWLEDGMENT}

The research grant is from Halal Institute of Prince of Songkla University, PSU.

\section{REFERENCES}

[1] Y. Aeidnoie and A. Thanonkaew, "Effect of pretreatment on physico-chemical properties of Pla-duk-ra," J. Thaksin University, year 15 issue 3, 2012.

[2] U.U. Modibbo, S. A. Osemeahon, M. H. Shagal, and M. Halilu, "Effect of moisture content on the drying rate using traditional open sun and shade drying of fish rom Njuwa Lake in North Eastern Nigeria," J. Applied Chemistry, vol. 7, pp. 41 - 45, Feb 2014.

[3] A. Thanonkaew, J. Rittijak and, S. Suriyapol, "Chemical compositions and some properties of traditional dry fermented catfish (Pla-duk-ra) in Patthalung Province," J. Thaksin University, vol. 12, 2009.

[4] S. Kiriratnikom, A. Kiriratnikom, P. Chocksawasdikorn, K. Reungklay, and A. Thanonkaew, "Cultivation of hybrid catfish (Clarias macrocephalus X Clarias gariepinus) in net cages with practical diet formulated for production to raw material of salted fermented catfish," The National Academic Conference Thaksin University $23^{\text {rd }}$, year 16 , issue $3,2013$.

[5] A. Thanonkaew, T. Juntachote, and S. Pecharat, "Effect of fermentation and drying on changes of lipid and protein in dry fermented catfish (Pla-duk-ra) produced from farmed catfish and wild catfish," J. Thaksin University, vol.12(3), January 2010.

[6] Decagon devices Fundamentals of Water Activity, 950 NE Nelson Court Pullman, Washington, 99163.

[7] S. Sumaila Onimisi and, A. Nasiru Sule, "Investigation of drying quality of yam (a staple food) from developed multipurpose food dryer," J. Engineering and Technology, vol. 6, June 2016.

[8] S. Bourdoux, D. Li, A. Rajkovic, F. Devlieghere and, M. Uyttendaele, "Performance of drying technologies to ensure microbial safety if dried fruits and vegetables," Comprehensive Reviews in Food Science and Food Safety, vol. 15, 2016.

[9] Approved Methods Manual Export Standards Branch, Exports Division Department of Agriculture, 2015.

[10] Y. Tian, Y. Zhao, J. Huang, H. Jeng and, B. Zheng, "Effects of different drying methods on the product quality and volatile compounds of whole Shiitake mushrooms," Food Chemistry, vol. 197, pp. 714 - 732, 2016.

[11] M. Kumar, S. K. Sansaniwal, P. Khaton, "Progress in solar dryer for drying various commodities," Renewable and Sustainable Energy Reviews, vol. 55, pp. 346 - 360, 2016.

[12] H. Darvish, M. Azadbaht, A. Rezaeiasl and, A. Farhang, "Drying characteristics of sardine fish dried with microwave heating," J. Saudi Society Agricul. Sci., vol 12, pp. 121-127, 2013. 